\section{Overpressure transmission through interconnected igneous intrusions}

\author{
Nick Schofield, Simon Holford, Alex Edwards, \\ Niall Mark, and Stefano Pugliese
}

\begin{abstract}
In situ overpressures in sedimentary basins are commonly attributed to disequilibrium compaction or fluid expansion mechanisms, although overpressures in shallow sedimentary sequences may also develop by vertical transfer of pressure from deeper basin levels, for example, via faults. Mafic sill complexes are common features of sedimentary basins at rifted continental margins, often comprising networks of interconnected sills and dikes that facilitate the transfer of magma over considerable vertical distances to shallow basinal depths. Here, we document evidence for deep sills (depths $>5 \mathrm{~km}$ [ $>16,000 \mathrm{ft}]$ ) hosting permeable, open fracture systems that may have allowed transmission of overpressure from ultradeep basinal ( $>7 \mathrm{~km}[>23,000$ $\mathrm{ft}])$ levels in the Faroe-Shetland Basin, northeast Atlantic margin. Most notably, well 214/28-1 encountered overpressured, thin $(<8 \mathrm{~m}[<26 \mathrm{ft}])$, and fractured gas-charged intrusions, which resulted in temporary loss of well control. Although the overpressure could reflect local gas generation related to thermal maturation of Cretaceous shales into which the sills were emplaced, this would require the overpressures to have been sustained for unfeasibly long timescales ( $>58$ m.y.). We instead suggest that transgressive, interconnected sill complexes, such as those penetrated by well $214 / 28-1$, may represent a previously unrecognized mechanism of transferring overpressures (and indeed hydrocarbons) laterally and vertically from deep to shallow levels in sedimentary basins and that they represent a potentially underrecognized hazard to both scientific and petroleum drilling in the vicinity of subsurface igneous complexes.
\end{abstract}

Copyright (C2020. The American Association of Petroleum Geologists. All rights reserved. Gold Open Access. This paper is published under the terms of the CC-BY license.

Manuscript received September 3, 2018; provisional acceptance January 14, 2019; revised manuscript received February 27, 2019; revised manuscript provisional acceptance March 18, 2019; 2nd revised manuscript received March 19, 2019; final acceptance May 9, 2019.

DOl:10.1306/05091918193

\section{AUTHORS}

Nick SCHOFIELD Department of Geology and Petroleum Geology, University of Aberdeen, Aberdeen, United Kingdom; n.schofield@abdn.ac.uk

Nick Schofield is a reader in igneous and petroleum geology at the University of Aberdeen, where he leads the Atlantic Margin Research Group. He has published approximately 50 papers on sill emplacement and the interaction of volcanism with petroleum systems. Nick has a Ph.D. from the University of Birmingham and a B.Sc. (Honors) from the University of Edinburgh

SIMON HOLFORD Australian School of Petroleum, University of Adelaide, Adelaide, South Australia, Australia; simon.holford@ adelaide.edu.au

Simon Holford is associate professor of petroleum geoscience at the University of Adelaide's Australian School of Petroleum, where he coleads the Stress, Structure, and Seismic Research Group. Simon has published approximately 90 papers on the prospectivity and tectonics of margins, petroleum geomechanics, and magmatism in basins. Simon has a Ph.D. from the University of Birmingham and a B.Sc. (Honors) from Keele University.

Alex EdWARDS Ikon Science Ltd., London, United Kingdom; aedwards@ ikonscience.com

Alex Edwards is the global portfolio manager for wells at lkon Science, having joined in 2009. He has been involved in all aspects of regional pore pressure analysis, pre- and post-well analysis. Alex received an MESci in geology (2005) from the University of Liverpool and a Ph.D. in structural geology at the University of Manchester.

NIALL MARK Department of Geology and Petroleum Geology, University of Aberdeen, Aberdeen, United Kingdom; niall.mark@ abdn.ac.uk

Niall Mark completed his Ph.D. in interactions of igneous intrusions with petroleum systems in 2019. He received an M.Sc. in hydrocarbon exploration from the University of Aberdeen in 
2014 and a B.Sc. (Honors) in earth science from Glasgow University in 2012.

Stefano Pugliese Chrysaor, London, United Kingdom; Stefano.Pugliese@ chrysaor.com

Stefano Pugliese is lead geoscientist with Chrysaor in the United Kingdom. He received his B.Sc. geology degree from the University of St. Andrews and a Ph.D. in igneous geology from Kingston University. His petroleum career began in Vietnam, looking at fractured basement plays, but over the last decade, he has focused on the traditional Cenozoic and Mesozoic plays of the North Sea.

\section{ACKNOWLEDGMENTS}

JX Nippon UK Ltd. are thanked for prestack depth migrated seismic data used in this study. Well data are from the Common Access Database. IHS Kingdom software and Schlumberger Petrel software were used for seismic interpretation. Schlumberger Techlog was used for the display of wireline and formation microimager data. We would like to thank Joe Cartwright, Richard Swarbrick, Clayton Grove, and Stephen O'Connor for the constructive and helpful reviews and discussions of this manuscript. We thank PGS for the continued support of the research group at Aberdeen. AAPG Editor Barry J. Katz is thanked for editorial guidance and input. Frances Whitehurst is thanked for editing advice.

\section{INTRODUCTION}

Abnormally high pore-fluid pressure, commonly referred to as overpressure, is a common occurrence within sedimentary basins, occurring when the pore-fluid pressure is greater than the hydrostatic pressure expected at a given depth (Neglia, 1979; Mann and Mackenzie, 1990; Osborne and Swarbrick, 1997; Tingay et al., 2007). Encountering unexpected overpressure zones during drilling operations can pose a significant risk to both human life, the environment, and a well achieving its technical objective; such zones can result in an influx of high-pressure gas or fluid into and up the wellbore (known as a "kick") and, in a worst-case scenario, a "blowout" (Grace, 2017). Accurate prediction of pore pressures when drilling petroleum wells fundamentally underlies safe drilling operations; the lack of adequate understanding and subsequent response to higher-than-expected pore pressures during drilling of the Banjar Panji-1 well in Java, Indonesia, was a contributing factor to the blowout and the flow of the Lusi mudflow that suddenly erupted in an urban area, burying over 11,000 buildings (Tingay, 2015).

It is generally accepted that disequilibrium compaction related overpressure cannot be sustained for long periods of geological time ( $>20 \mathrm{Ma}$ ) within a sedimentary basin, with the overpressure dissipating via fluid leakage (Osborne and Swarbrick, 1997; Swarbrick et al., 2001; Tingay et al., 2007; Luo and Vasseur, 2016). Critically, it is also generally assumed that overpressure exists close to where it is generated (Osborne and Swarbrick, 1997). The transfer of overpressure horizontally or vertically within sedimentary basins has not been widely documented globally, with a few notable exceptions. Tingay et al. (2007) demonstrated the likely vertical transfer of overpressure up normal faults within the inner shelf of the Baram Delta, Borneo. Other notable areas where such pressure transfer is documented include that of the Northern Carnarvon Basin, northwest Australia shelf (van Ruth et al., 2000; Dodds et al., 2001; Tingate et al., 2001; Hoskin et al., 2015), and the Qaidam Basin, northwest China (Fan et al., 2016).

Here, we detail the occurrence of overpressure within igneous intrusions in the Faroe-Shetland Basin (FSB), using a combination of subsurface data sets. We propose a new mode of overpressure transfer via interconnected networks of fractured igneous intrusions. We then discuss the ramifications of such an "overpressure" transfer mechanism for both petroleum and scientific drilling in sedimentary basins containing extensive igneous intrusions (e.g., northwest shelf of Australia, South Atlantic margin, Norwegian margin, Guaymas Basin), emphasizing the need to plan for the possibility of encountering significantly higher-than-expected pore-fluid pressures in the vicinity of igneous sheet intrusions. 


\section{GEOLOGICAL HISTORY AND PETROLEUM EXPLORATION HISTORY OF THE FAROE-SHETLAND BASIN}

The FSB is located between the Faroe Islands and Shetland Islands within the Atlantic passive continental margin of northwest Europe (Figure 1). The FSB can be divided into a series of southwestnortheast-trending subbasins and is quasicontiguous with the Rockall Trough to the southwest and the Møre Basin to the northeast (Hitchen and Ritchie, 1987). The subbasins consist of Mesozoic to Holocene sedimentary rocks bounded by basement highs composed of Precambrian crystalline rocks capped by Paleozoic and Mesozoic sedimentary rocks (Lamers and Carmichael, 1999).

The tectonic evolution of the FSB is complex and encompasses a number of rifting phases and compressional events that span a time period of approximately 400 m.y., from the Devonian to the Cenozoic. Much of the present-day structure and past rifting history is thought to have been heavily controlled by the northeast-southwest-trending basement grain, which formed throughout northwest Scotland during the Caledonian orogeny during the Ordovician to early Devonian. The first widespread phase of rifting within the basin was initiated during the Permian-Triassic, taking place along the existing northeast-southwest Caledonian structural grain. This produced a series of half-graben basins filled with fluvial, eolian, and lacustrine sequences. Thermal subsidence and rising global sea level led to an Early Jurassic marine incursion (Booth et al., 1993), with thermal subsidence continuing into the Middle Jurassic. Into the Late Jurassic, the FSB underwent renewed rifting, linked to the establishment of extensive rifting within the North Sea. However, detailed evidence of Late Jurassic extension within the FSB is limited by poor seismic imaging beneath the Paleocene-Eocene sill complex (Schofield et al., 2015). The Early Cretaceous was marked by high-magnitude extension as a result of the northward propagation of the central Atlantic rift system (Stoker, 2016), leading to hyperextension along the northeast Atlantic margin (Booth et al., 1993; Doré et al., 1997; Moy and Imber, 2009).

The North Atlantic rift system became relatively inactive during the Late Cretaceous, with postrift thermal subsidence facilitating the deposition of up to $4.5 \mathrm{~km}(14,763 \mathrm{ft})$ of Upper Cretaceous sedimentary rocks on the downthrown side of the major fault systems. During the Paleocene, relative deep-water marine conditions existed with the deposition of hemipelagic shales and turbidite sandstones (Lamers and Carmichael, 1999) as part of continued postrift thermal subsidence.

However, during the late Paleocene-early Eocene, the FSB experienced considerable igneous activity as a result of the impinging proto-Icelandic plume coinciding with the continental break-up of the North Atlantic (White and McKenzie, 1989). This igneous activity is expressed by the eruption of extrusive basaltic sequences and the emplacement of a pervasive suite of mafic sills and dykes into the sedimentary basins flanking the northeast Atlantic margin (Figure 2) (Gibb and Kanaris-Sotiriou, 1988; Schofield et al., 2015). Mafic intrusions are identified throughout the FSB, where they are collectively termed the Faroe-Shetland sill complex (FSSC), and extending northward into the Møre Basin and south into the Rockall Trough (Schofield et al., 2017). Critically, the FSSC, and the sills in other Atlantic margin basins, are observed to preferentially intrude the Cretaceous and lower Paleocene sedimentary succession, which is predominantly composed of marine shales (Stoker, 2016) and represents a significant lowpermeability sealing unit (Ogilvie et al., 2015).

The FSB has seen active exploration for the last 50 yr with the first well (206/12-1) drilled in 1972 on the Rona Ridge and over 200 exploration and appraisal wells in total drilled in the FSB. Reservoirs are present throughout the entire basin succession, from the fractured Lewisian Gneiss Complex crystalline basement (Lancaster field), fractured siliclastics in the Devonian and Carboniferous Old Red Sandstone (Clair field), Jurassic sandstones (Lochnagar discovery), Cretaceous (Victory discovery and Edradour field) and Paleocene turbidites (Schiehallion, Laggan-Tormore, Glenlivet fields, and Cragganmore discovery), Paleocene-Eocene intrabasaltic fluvial deltaic sandstones (Rosebank field), Lower Eocene supra-basaltic sandstones (Cambo field), and mid-Eocene turbidite fan sandstones (Tobermory discovery). The majority of hydrocarbons discovered are sourced from the marine Upper Jurassic Kimmeridge Clay Formation, although in some areas, Middle Jurassic lacustrine (Scotchman et al., 2018) and Middle Devonian lacustrine (Baron et al., 2008) sources are thought to contribute. 


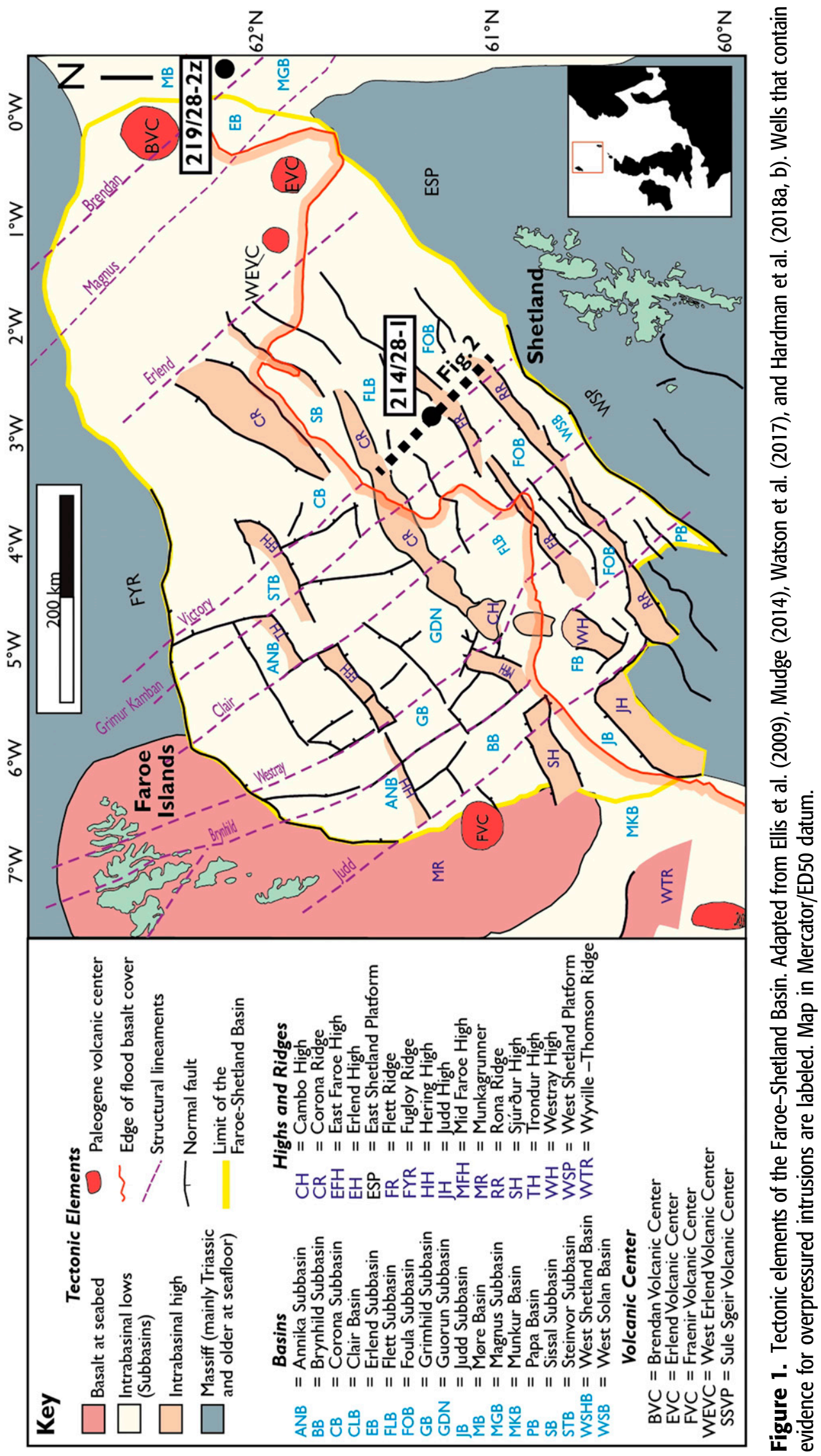



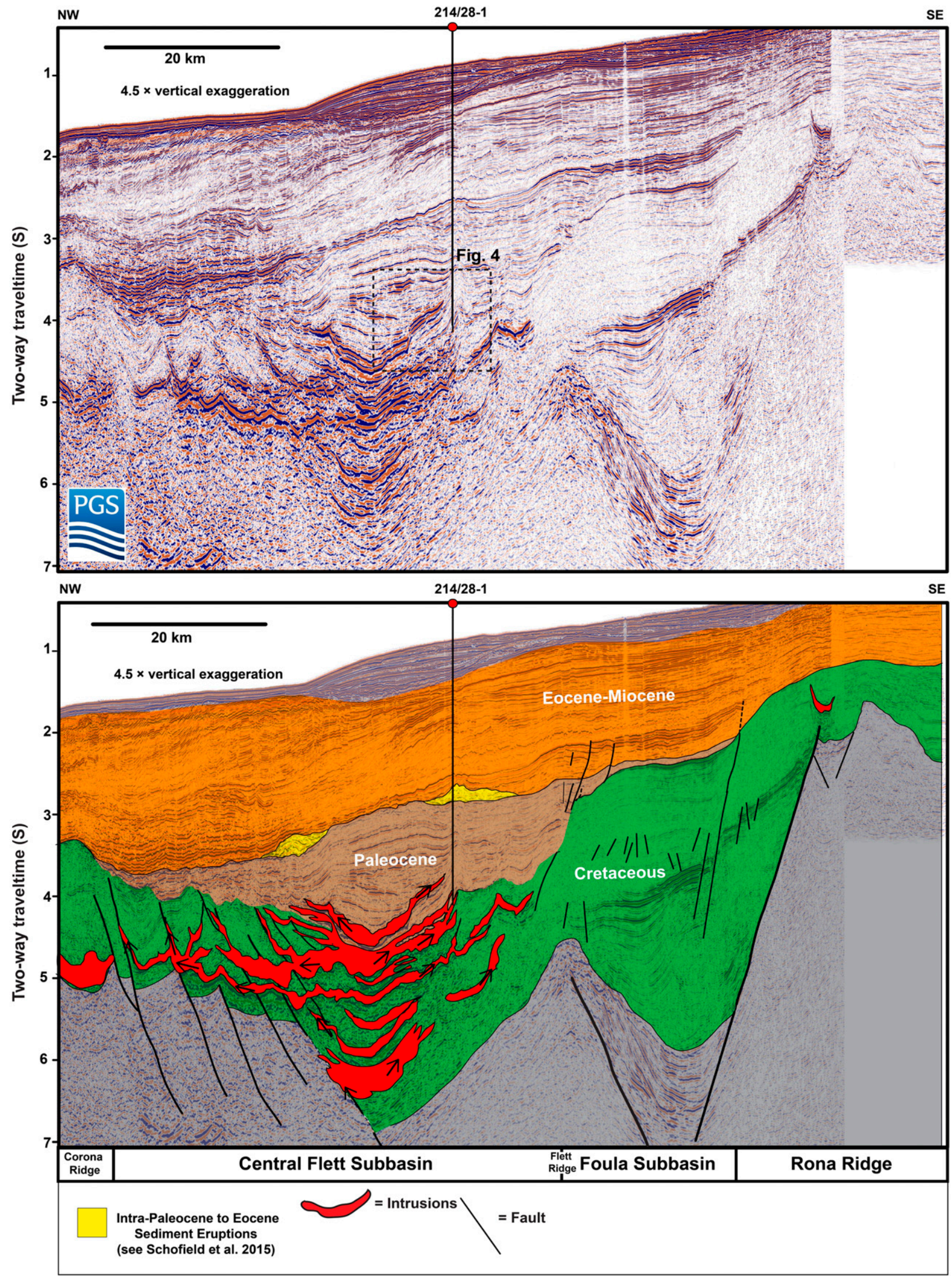

Figure 2. Regional seismic line through well 214/28-1. Data courtesy of PGS-Faroe-Shetland Basin MegaSurvey plus. 


\section{OVERPRESSURE DEVELOPMENT WITHIN THE FAROE-SHETLAND BASIN}

Understanding the interplay of pore pressures and their impact on petroleum generation during basin evolution is essential for any petroleum exploration and has particular importance in the FSB because of the tectonic complexity (Iliffe et al., 1999). Despite extensive exploration activity in the FSB, a full quantitative analysis of the depthpore pressure relationships remains poorly documented in the literature. However, some broad conclusions can be drawn about the pressure history of the FSB.

Measured reservoir pressure data show that the majority of the wells in the West of Shetlands region exhibit normally pressured or near-normally pressured gradients (Iliffe et al., 1999; Lamers and Carmichael, 1999). However, overpressure is known to occur within Mesozoic sections at depths greater than $3000 \mathrm{~m}$ (>9842 ft), with Lower Cretaceous sequences generally exhibiting the largest formation overpressures (Iliffe et al., 1999; Tassone et al., 2014). The distribution of overpressure within the FSB is, however, not uniform, with both normally pressured and overpressured high-permeability sands occurring at similar depths. This implies that a complex basin plumbing and fluid drainage system is in operation within the FSB (Edwards et al., 2012). It is generally accepted that disequilibrium compaction, as a result of high sedimentation rates in the Cenozoic, is the dominant mechanism that has created the large-magnitude (>20 MPa [ $>2901$ psi]) overpressure within the Mesozoic sections of the FSB (Iliffe et al., 1999). The observation in velocitydensity crossplot space, in the absence of $\mathrm{x}$-ray diffraction-type data, shows there are no deviations of data from a normal compaction trend and, hence, supports the notion that disequilibrium compaction is primarily active (Figure 3 ). It should also be noted that although the FSB has undergone multiple phases of tectonic uplift (Stoker et al., 2010), the two wells of interest in this study are located in subbasins that have undergone negligible uplift, as demonstrated by Cretaceous shale compaction data (Tassone et al., 2014).

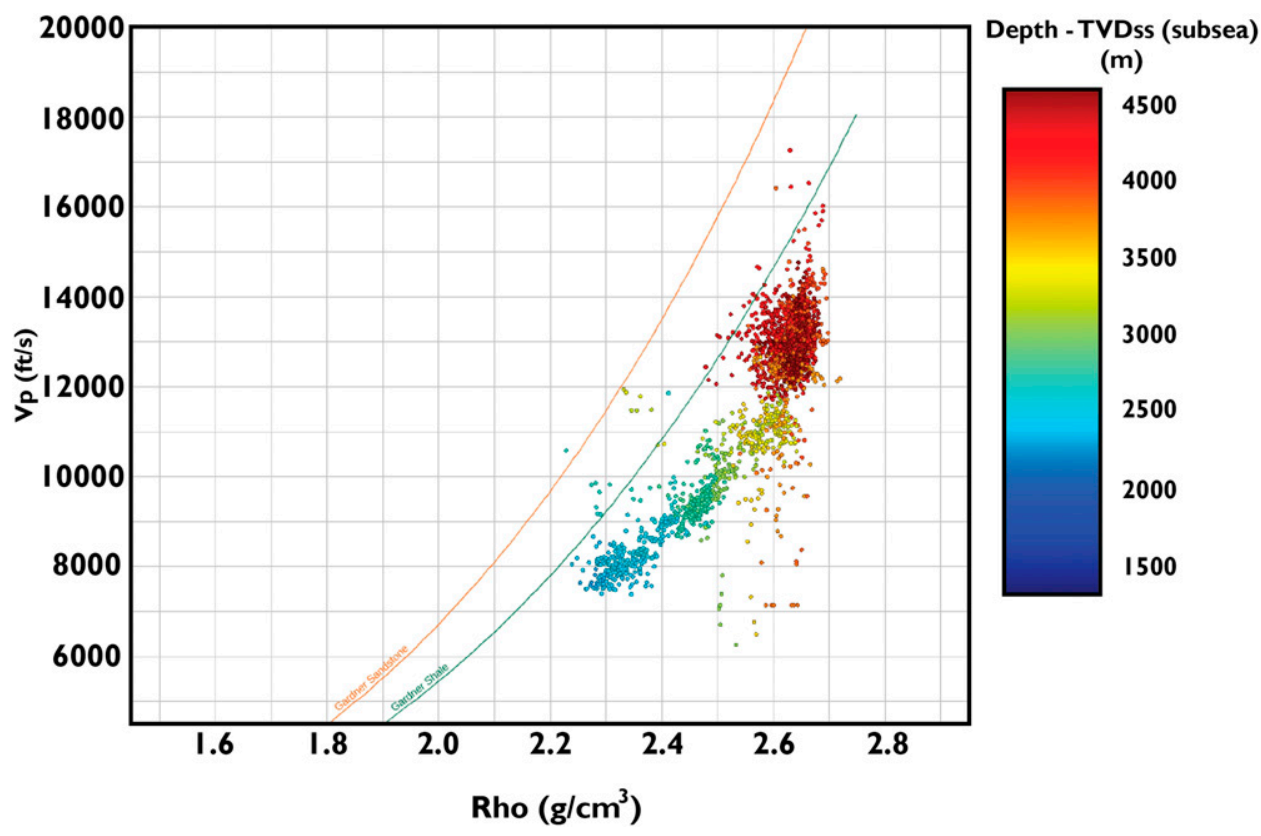

Figure 3. Velocity (Vp) versus density (Rho) crossplot for well 214/28-1. Examining Vp and Rho relationships can reveal information about the mechanism of overpressure development (Lahann et al., 2001, following the work of Bowers, 1995). The deepest shales (Cretaceous age) do not deviate from the Gardener shale trend, which is indicative of disequilibrium compaction as the sole pressure mechanism. The density values, however, exceed $2.45 \mathrm{~g} / \mathrm{cm}^{3}$ (typical maximum density because of mechanical compaction), which suggests low-porosity shales. The corrected bottomhole temperature is $167^{\circ} \mathrm{C}$, and therefore the high-density values correspond to diagenetic shale alteration. TVDss = total vertical depth subsea. 
OVERPRESSURED INTRUSIONS

\section{Well 214/28-1-Flett Ridge}

Well 214/28-1, drilled in the FSB in 1984 to a total depth of $5124 \mathrm{~m}$ below rotary table (BRT) $(16,811 \mathrm{ft}$ BRT) (653 m [199 ft] water depth), was designed to test Paleocene and Jurassic targets (Grove, 2013). However, the well encountered substantial issues with overpressured mafic intrusions between 4596 and $5013 \mathrm{~m}$ BRT (15,078-16,446 ft BRT) (Figure 4), which required the expenditure of considerable time and effort to control the overpressure and gas influx (Mark et al., 2017). The intrusions penetrated by well 214/28-1 form a series of vertically stacked intrusions that extend down toward the center of the Flett Basin and the base of the Cretaceous sequence (Schofield et al., 2015) (Figure 2).

Using direct (e.g., wireline formation tester, repeat formation tester [RFT], and modular formation dynamic tester [MDT]) and indirect (e.g., mud weights) pressure data indicates a consistent picture of broadly hydrostatic pressures to depths of approximately $3200 \mathrm{~m}(\sim 10,498 \mathrm{ft})$ within the middle Paleocene (Figure 5). Below this depth, RFT and MDT data begin to indicate a departure from normal hydrostatic conditions and occurrence of overpressure, which increased gradually with small deviations (e.g., $4100 \mathrm{~m}$

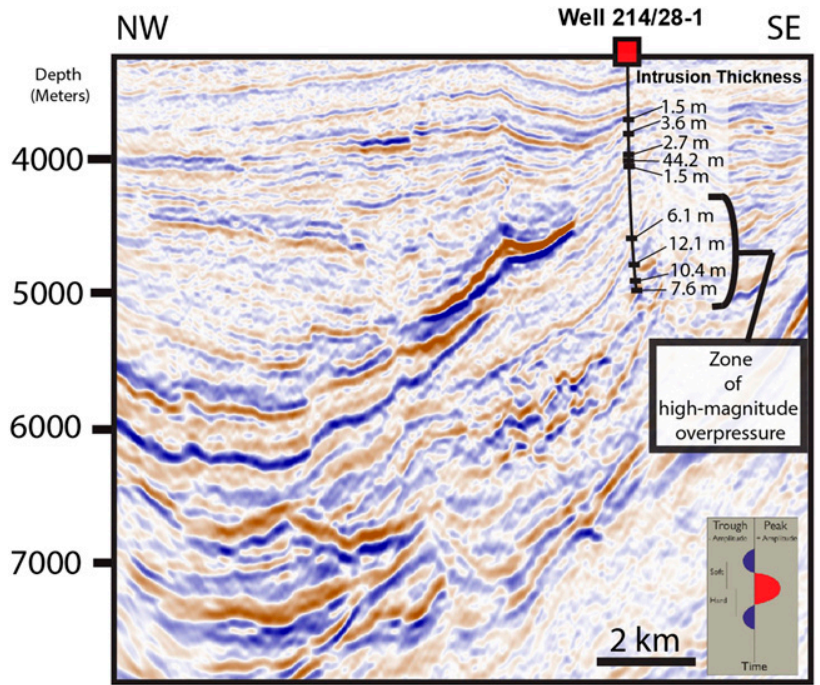

Figure 4. Seismic line through well 214/28-1 located in the Faroe-Shetland Basin, offshore northwest Scotland. The seismic line is from a three-dimensional cube acquired in 2011-2012, reprocessed to prestack depth migration in 2016. The lower zone of intrusions, where overpressure was encountered (Figures 5, 6), extend in a downdip direction toward a depth of approximately $6.5 \mathrm{~km}(\sim 21,325 \mathrm{ft})$.

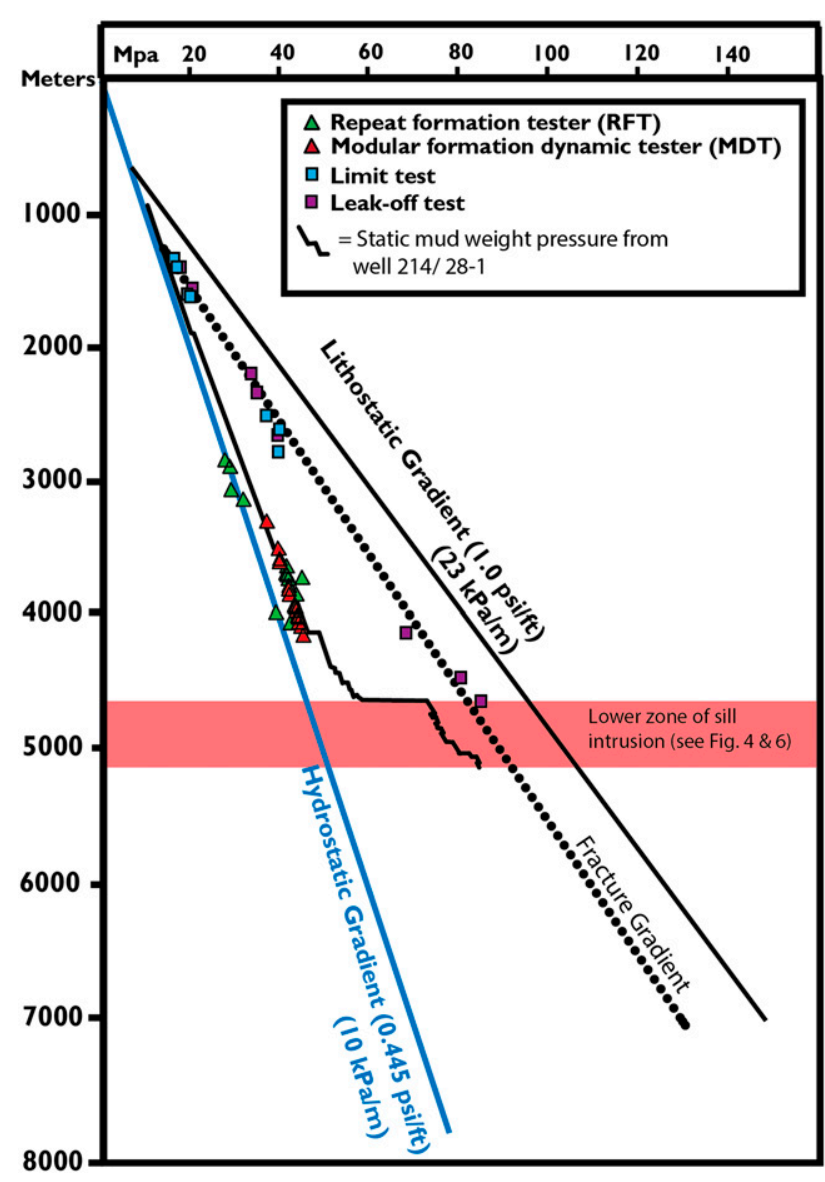

Figure 5. Pressure versus depth plot. Direct pressure data (e.g., repeat formation tester) from well 214/28-1 and well 214/ 27-1 (located $10 \mathrm{~km}$ [6 mi] away, which penetrated same stratigraphic succession).

BRT $[13,451 \mathrm{ft}$ BRT]). The top of the overpressure was estimated using intermediate wire-line logs during drilling operations and was found at approximately $4480 \mathrm{~m}$ BRT $(\sim 14,698 \mathrm{ft}$ BRT) (Figure 5). This depth is consistent with regionally built shale models in the West of Shetlands region (Edwards et al., 2012; Tassone et al., 2014). However, on encountering a $6.1-\mathrm{m}(20-\mathrm{ft})$-thick intrusion at a subseabed depth of $4596 \mathrm{~m}$ BRT $(15,075 \mathrm{ft}$ BRT) (Figures 4-6), a large-magnitude overpressure was encountered associated with high-pressure gas influx into the wellbore and 44\% total gas (methane, ethane, propane, and butane) (Figures 5, 6). Using the static mud weight pressure as a proxy for pore pressure in absence of direct pressure data (e.g., RFT) at this interval (van Ruth et al., 2002), the circulating mud weight had to be increased to control the pore pressure increase and associated gas from approximately $57 \mathrm{MPa}(\sim 8267 \mathrm{psi} ; 10.5 \mathrm{ppg})$ to greater than $71 \mathrm{MPa}$ 


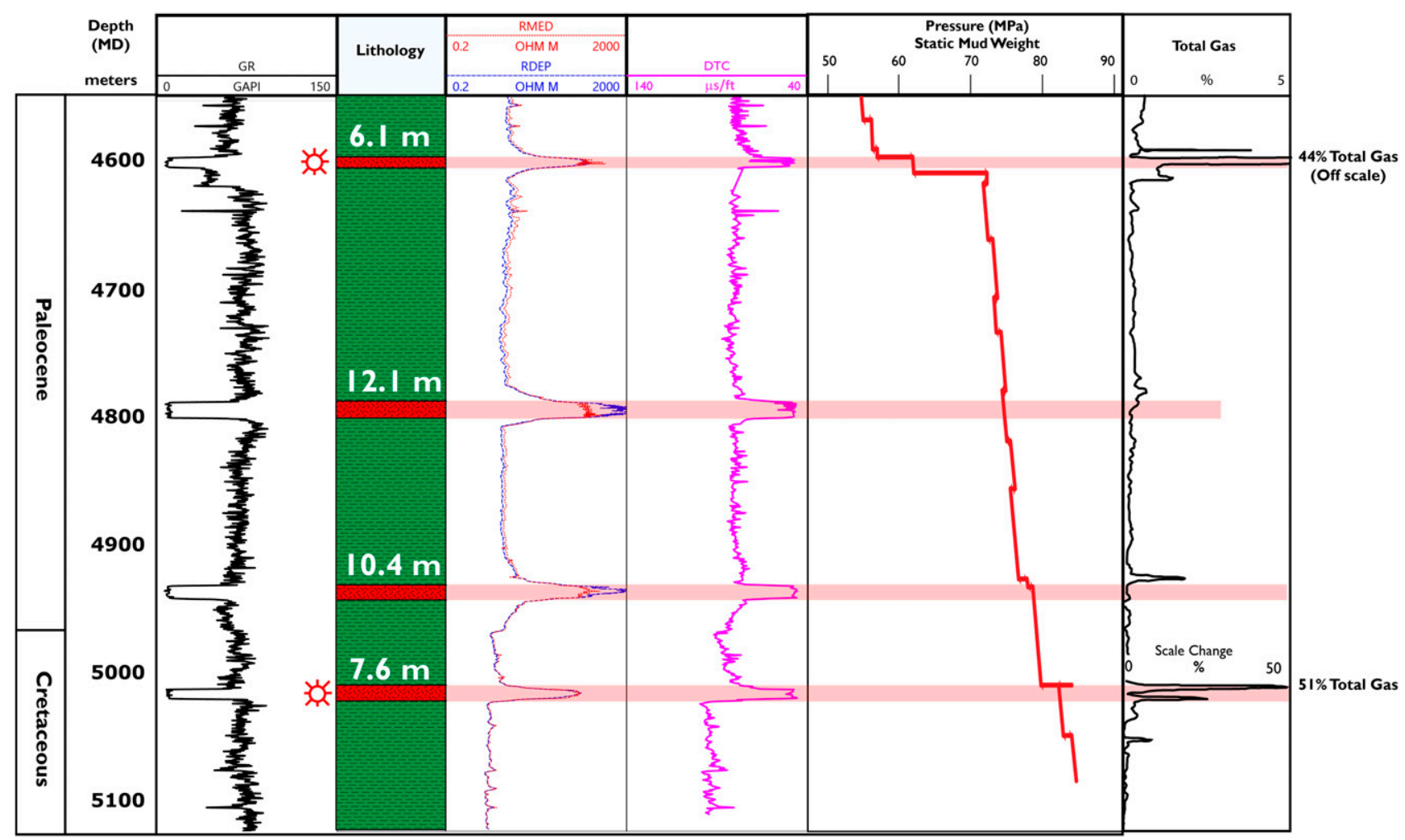

Figure 6. Diagram showing log responses, static mud weight (megapascals), and total gas from the lower zone of intrusions where overpressure was encountered in well 214/28-1. DTC = sonic traveltime; GAPI = gamma ray, API; GR = gamma ray; RDEP = deep resistivity; RMED = medium resistivity.

(>10,296 psi; 13.1 ppg) (Figures 5, 6). On continuation of drilling, with the increased mud weight, two further intrusions where penetrated at $4788 \mathrm{mBRT}(15,708 \mathrm{ft}$ BRT) and $4931 \mathrm{~m}$ BRT (16,177 ft BRT), respectively, with no further influx of gas noted (Figure 6). However, at a depth of $5013 \mathrm{~m}$ BRT $(16,446 \mathrm{ft}$ BRT), a 7.6-m (25-ft)-thick overpressured intrusion was encountered (Figure 6), with mud weights having to be raised further to counteract the estimated pressure of greater than $82 \mathrm{MPa}(>11,893 \mathrm{psi} ; 13.9 \mathrm{ppg})$. Associated with this intrusion was $51 \%$ total gas (methane), which, when expanding at the surface, led to mud flowing out over the kelly bushing and partial loss of well control. After penetration of the $7.6-\mathrm{m}(25-\mathrm{ft})$-thick intrusion, connection gas values remained at $30 \%-45 \%$, even at the increased levels of mud weight to the base of the hole at $5124 \mathrm{~m}$ BRT $(16,811 \mathrm{ft} \mathrm{BRT})$.

\section{Well 2 19/28-2Z-Northern Faroe-Shetland Basin}

Well 219/28-2Z was drilled to a total depth of $4016 \mathrm{~m}$ BRT $(13,175 \mathrm{ft}$ BRT) (516 m [1692 ft] water depth) in the northeast of the FSB and southern extension of the Møre Basin, approximately $20 \mathrm{~km}(\sim 12 \mathrm{mi})$ northward of the Margarita Spur. The well penetrated a 36-m (118-ft)-thick intrusion at $3148 \mathrm{~m}$ BRT $(10,328 \mathrm{ft}$ BRT) $(-3.1 \mathrm{~s}$ two-way traveltime) (Figures 7,8$)$. On seismic data, the intrusion is poorly imaged because of the deep depth of imaging and inclined $\left(\sim 40^{\circ}\right)$ nature of the intrusion. However, the intrusion can be seen to connect subvertically to a series of sills intruded into the Lower Cretaceous succession. Although initially the intrusion (which was associated with a small gas peak ranging from $0.78 \%$ to $1.92 \%$ ) was estimated to have a pore pressure between 39 and $40 \mathrm{MPa}$ (5706-5923 psi; 10.5-10.9 ppg), a direct RFT measurement taken at the lower intrusion contact gave a pore pressure measurement of $48 \mathrm{MPa}$ (6956 psi; $12.8 \mathrm{ppg}$ ) (Figures 8, 9), with the well completion report noting that the high pore pressure was probably confined entirely to the sill and that the adjacent claystone appeared to have been at a substantially lower pressure gradient. 

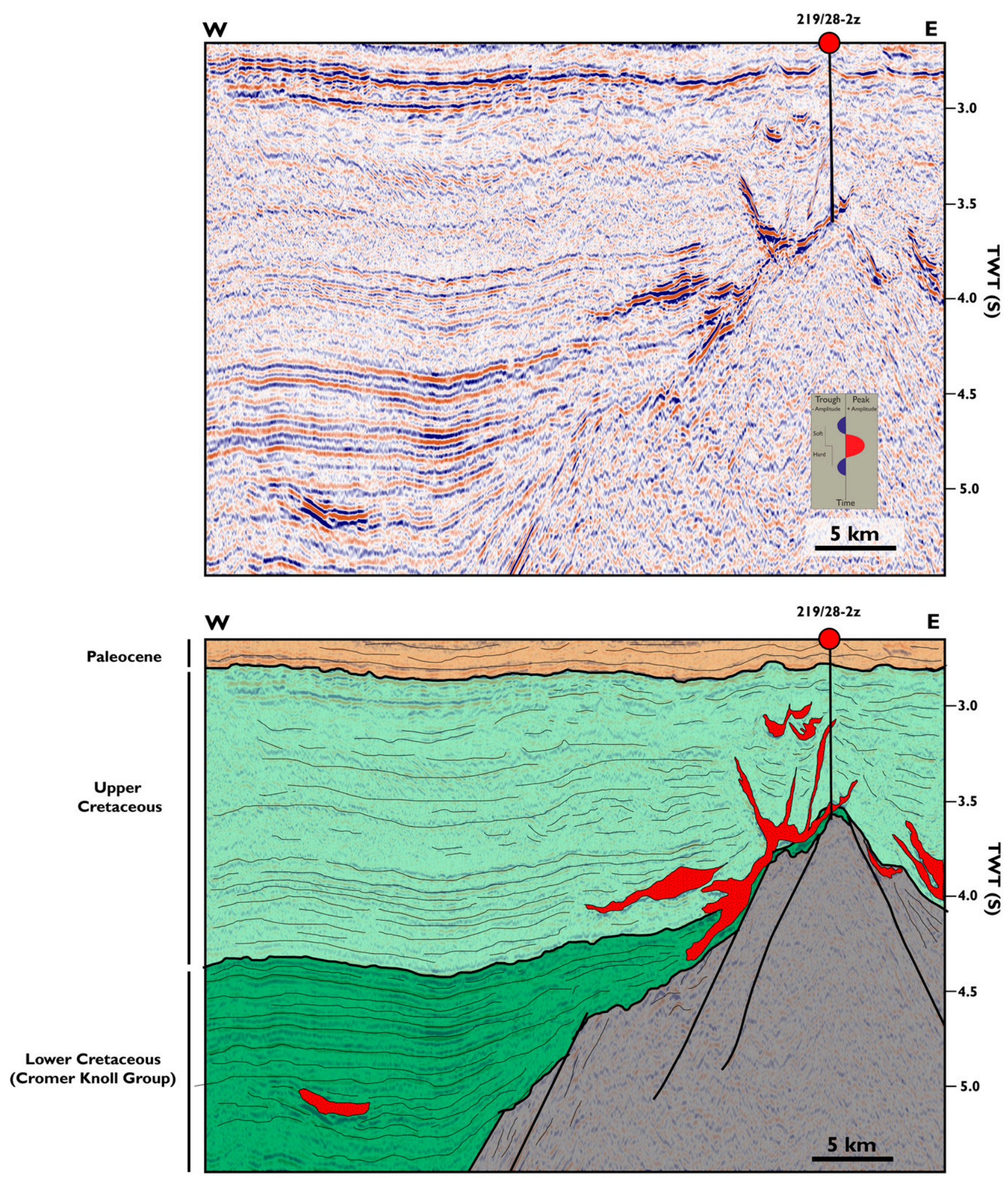

Figure 7. Two-dimensional seismic line (NS92202) across well 219/28-2Z, showing inclined intrusion, which was penetrated at $3048 \mathrm{~m}$ $(10,000 \mathrm{ft})$ below rotary table $(\sim 3.1 \mathrm{~s}$ two-way traveltime [TWT]). Red coloring indicates intrusions. 


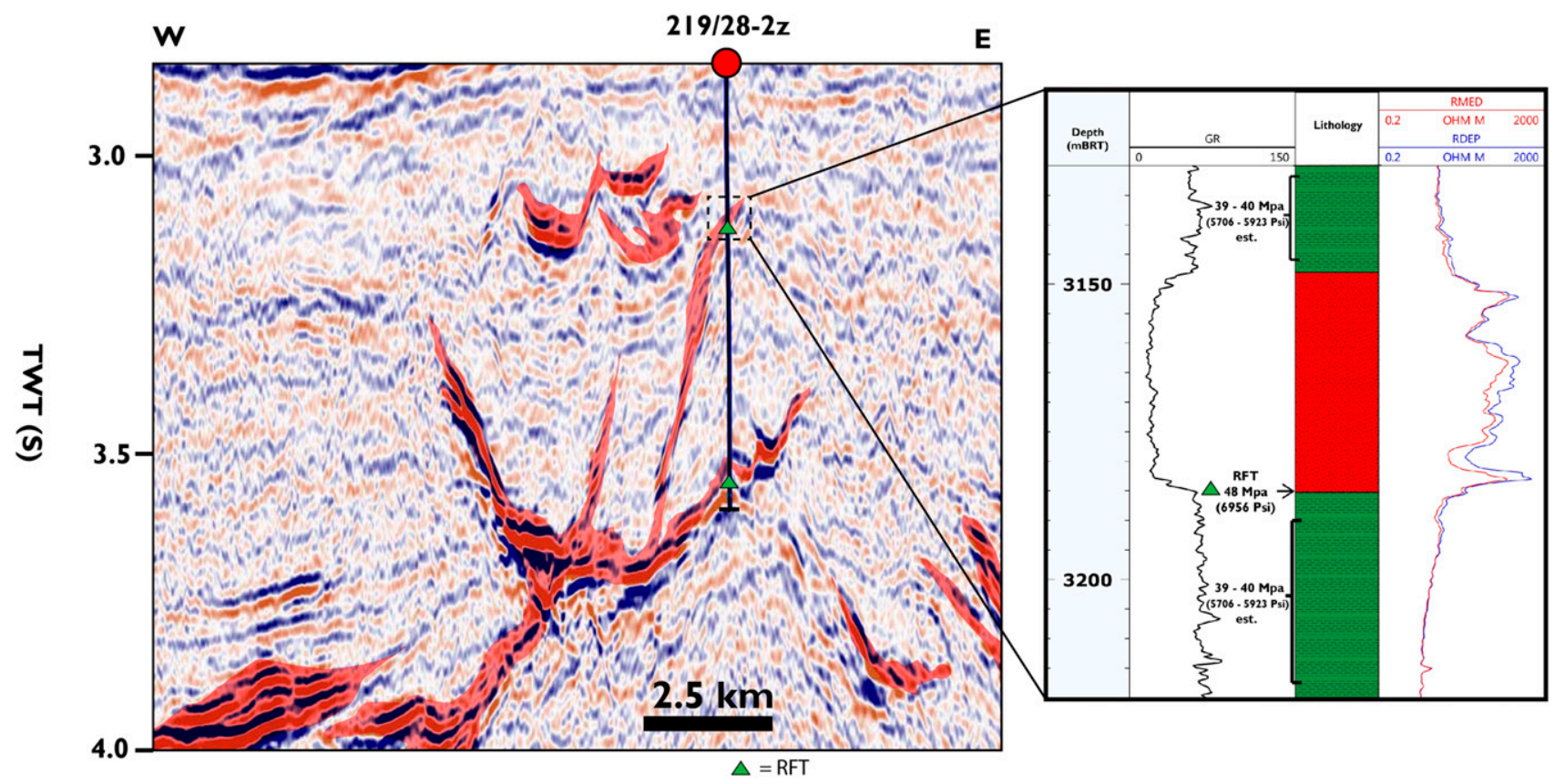

Figure 8. Detail of a sill (red) penetrated at $3148 \mathrm{~m}(10,328 \mathrm{ft})$ below rotary table (BRT). A repeat formation tester (RFT) measurement taken at the sill edge recorded a pressure of $48 \mathrm{MPa}$ (6956 psi), some $8 \mathrm{MPa}(1160 \mathrm{psi})$ higher than the surrounding sequences. This pressure was equivalent to that recorded in RFT measurements at the base of the well. This suggests that the sill penetrated at $3148 \mathrm{~m}$ BRT $(10,328 \mathrm{ft}$ BRT $)$ was in pressure communication with deeper units. Red coloring denotes intrusions. est. = estimate; RDEP = deep resistivity; RMED = medium resistivity; TWT = two-way traveltime.

\section{DISCUSSION}

\section{Overpressure Generation}

Although fluid expansion can occur by a variety of mechanisms (e.g., aquathermal expansion, diagenesis; see Tingay et al., 2013), kerogen to gas maturation is generally regarded as the dominant fluid expansion mechanism by which high-magnitude overpressure, equivalent to that formed by disequilibrium compaction, can be generated (Swarbrick and Osborne, 1998; Tingay et al., 2007). The emplacement of mafic, Paleogene intrusions into the Cretaceous claystone sequences of the FSB could lead to gas generation, as a result of localized maturation of organic matter by the intrusions (Aarnes et al., 2010; Muirhead et al., 2017). However, we argue against this mechanism for the overpressure witnessed within the intrusions penetrated in wells 214/28-1 and 219/28-2Z. First, multiple studies have shown that petroleum source potential is generally lacking in the Cretaceous and Cenozoic stratigraphy, and hence, the local host rocks are likely to be poor source rocks for gas (Scotchman, 2001; Scotchman et al., 2018). Second, overpressures are inherently unstable, with pore-fluid pressures always attempting to return to hydrostatic equilibrium (Osborne and Swarbrick, 1997). The residence time of overpressure related to disequilibrium compaction is generally less than $20 \mathrm{Ma}$ (Luo and Vasseur, 2016). Therefore, having overpressure maintained from $58 \mathrm{Ma}$, when the sills were emplaced, would exceed the generally accepted upper maximum timescale in which overpressure is thought to be sustainable within most sedimentary basins.

\section{Fractures within Intrusions}

Exposed basaltic sill intrusions are commonly pervaded by open fractures, both vertical and horizontal, in the form of cooling joints, which can create substantial fracture connectivity (Bermúdez and Delpino, 2008; Rateau et al., 2013; Senger et al., 2015). However, because of the unloading associated with the exhumation of such intrusions to contemporary surface levels, it is often difficult to assess whether open fractures visible in surface 


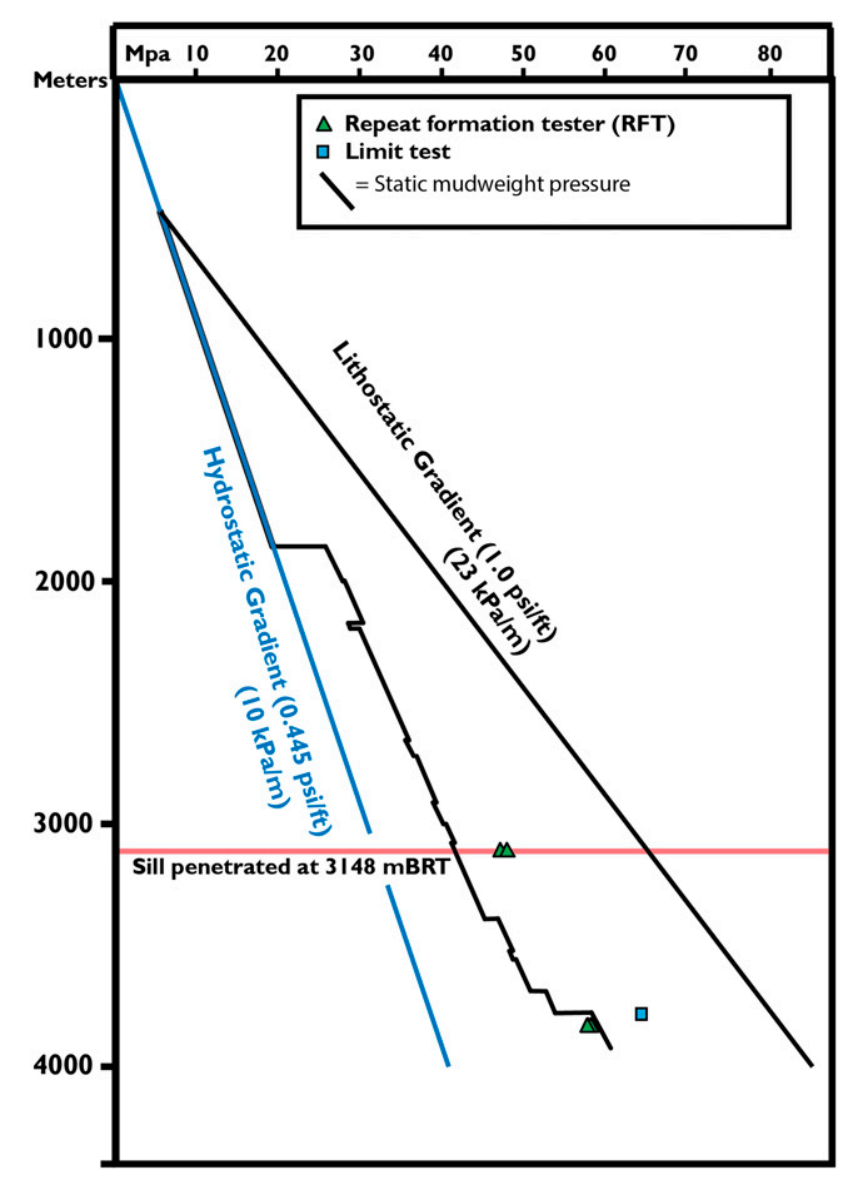

Figure 9. Pressure versus depth plot for well $219 / 28-2 Z$. BRT = below rotary table.

outcrops (e.g., Senger et al., 2015) would still be open and interconnected in deeply buried intrusions.

Multiple intrusions encountered within the FSB have caused substantial mud losses during drilling (Rateau et al., 2013; Mark et al., 2017). In an extreme case, 23,000 bbl of drilling mud was lost into a 60-m (197-ft)-thick fractured intrusion in the FSB (208/15-1A; Mark et al., 2017). In total, of the 29 wells that have encountered intrusions in the FSB, more than $80 \%$ have suffered some degree of mud loss when drilling through intrusions (Rateau et al., 2013; Mark et al., 2017).

Additionally, open fractures within intrusions along the Atlantic margin have been inferred to control the location of oil and gas accumulations (e.g., Tormore field) by acting as migration "superhighways" through low-permeability Cretaceous sequences (Rateau et al., 2013; Schofield et al., 2015, 2017). In Svalbard, the intrusions and surrounding contact metamorphic aureoles have been inferred to control fluid-flow and gas-escape structures adjacent to intrusions on the sea floor (Senger et al., 2013).

The open nature of fractures within subsurface igneous intrusions, even at depth, can be substantiated directly, when available, from borehole image resistivity logs (e.g., formation microimager [FMI], azimuthal focused resistivity, oil mud reservoir imager). In Figure 10, an FMI log through an igneous intrusion encountered at $3265 \mathrm{~m}$ BRT $(10,711 \mathrm{ft}$ BRT) within the subsurface shows clear evidence of open horizontal and vertical fractures within a 27-m (88-ft)-thick intrusion. We interpret the subvertical fractures, which extend greater than $30^{\circ}$ around the circumference of the hole, to be primary cooling fractures and not drilling induced because no subvertical fractures are seen in the weaker shale horizons above and below the intrusion and no change in mud weight occurred while drilling from the shale through to the intrusion. Additionally, cores obtained from intrusions within the FSB have also been shown to contain open vertical and importantly horizontal natural fracture sets (i.e., not induced by drilling) (Rateau et al., 2013; C. Grove, 2019, personal communication).

Associated with the fractures observed in the FMI log in Figure 10 is an increase in separation between the logged medium and deep resistivity within the wire-line logs. In the areas of clear fracturing on the FMI log (Figure 10), the medium resistivity, which measures the rock and pore fluids close to the wellbore $(\sim 1.5 \mathrm{~m}[\sim 5 \mathrm{ft}])$, is lower because of the invasion of the water-based mud into the sill via the fractures (thus reducing resistivity). The deep resistivity, however, remains high because it is measuring the virgin formation farther away from the borehole where the formation has not been invaded by the water-based mud. This same resistivity separation relationship appears to be demonstrated within well 219/28-2Z, where the resistivity separation within the intrusion where the elevated pore pressure was recorded by the RFT can be seen clearly (Figure 8).

In the case of well 214/28-1, the main evidence for the presence of fractures is the occurrence of the gas-related kicks associated with the 6.1-m (20-ft)and 7.6-m (25-ft)-thick intrusions (Figures 5, 6). Because intrusions usually possess zero effective 


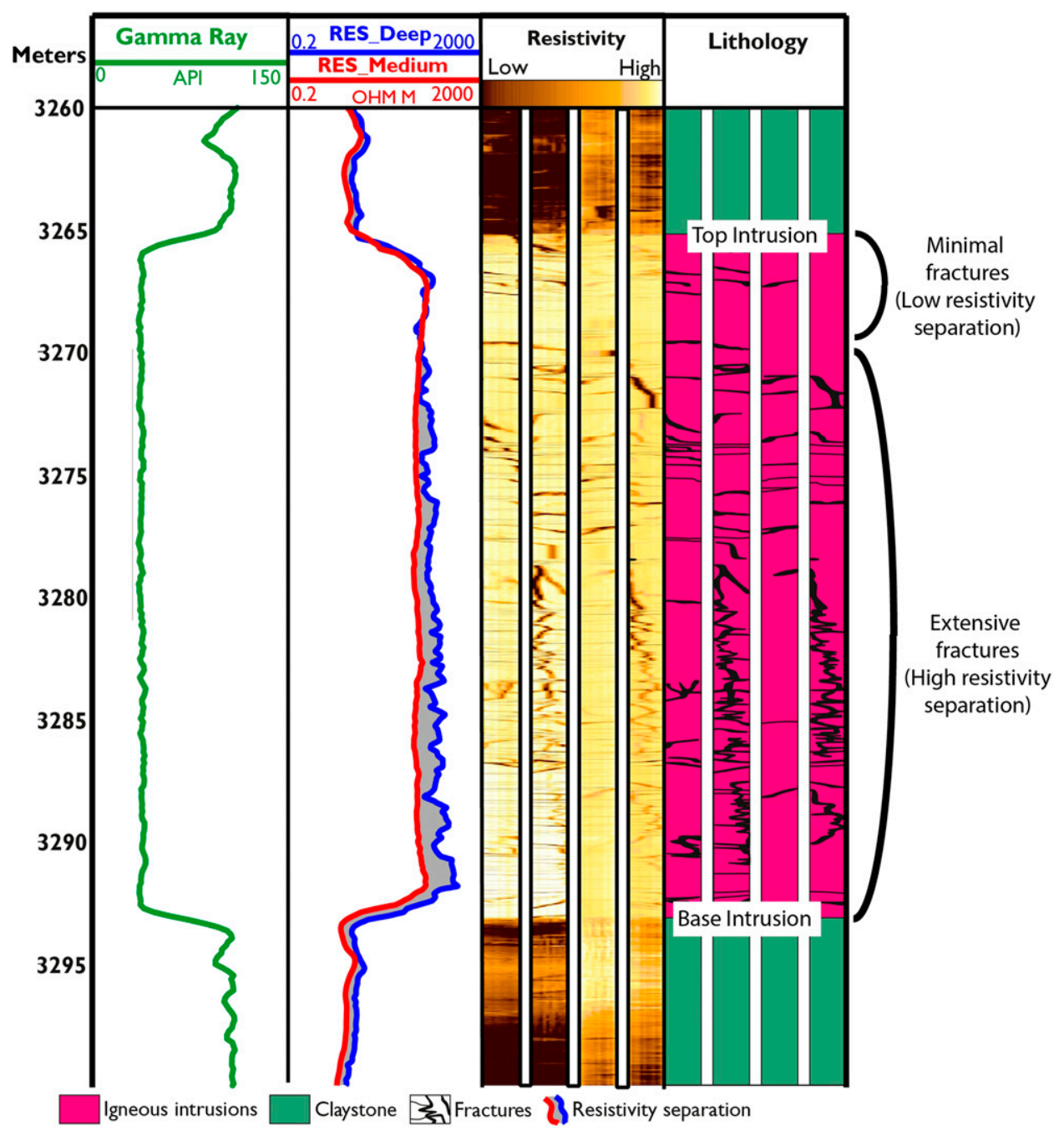

Figure 10. Wire-line and formation microimager (FMI) log through a 27-m (88-ft)-thick igneous intrusion located within the Faroe-Shetland Basin (213/27-2). Clear fractures can be observed within the intrusion on the FMI log. We interpret the subvertical fractures, which extend more than $30^{\circ}$ around the circumference of the hole, to be primary cooling fractures and not drilling induced because no subvertical fractures are seen in the weaker shales horizons above and below the intrusion and no change in mud weight occurred while drilling from the shale through to the intrusion. Note the increased separation of the deep and medium resistivity (RES_Deep and RES_Medium, respectively) wireline measurements within the heavily fractured area of the intrusion from approximately $3270 \mathrm{~m}(\sim 10,728 \mathrm{ft})$ to base of intrusion, and how this separation is greatly reduced within the zone of minimal fracturing toward the top of the intrusion and within the claystone sequence.

primary intergranular porosity, permeability is usually created by the presence of interconnected primary or secondary fractures (Bermúdez and Delpino, 2008; Rateau et al., 2013).

Interpretation of resistivity profiles in well 214/ 28-1 is complicated because the section in which the intrusions are present was drilled with an invertemulsion oil-based mud. Within the suite of intrusions in which overpressure was encountered (Figure 6), a clear separation in resistivity is visible within two of the sills, implying potential open fractures within the intrusions. However, this relationship is inverse to what would be expected with an oil-based mud, and therefore, in the absence of image log data (which was not collected) and other uncertainties (e.g., water saturation in the intrusion), it is difficult to interpret the resistivity separation as being fracture related with total confidence. Interestingly, a resistivity separation is not visible within the two overpressured intrusions (detailed previously). This lack of resistivity separation could be the result of the drilling mud being unable to invade into the fracture network of 
the intrusion because of the outward force of the gas (although balanced during logging), preventing the invasion of the drilling mud into fractures, thus preventing a resistivity contrast.

The intrusions within the FSB have never been exhumed or substantially uplifted since their emplacement. This suggests the fractures found in the intrusions at depth are probably the result of normal cooling and contractional processes within the intrusions at the time of emplacement (Bermúdez and Delpino, 2008). When the fractures became open is more difficult to assess and still unclear, although compressional inversion did occur within the FSB from the Miocene to the Oligocene, which may have reactivated existing fractures or created new fractures within the intrusions (Ritchie et al., 2008).

\section{Overpressure Transmission via Fractured Sills}

Igneous intrusions within sedimentary basins commonly form highly interconnected complexes; Cartwright and Møller Hansen (2006) documented this phenomenon on the Norwegian margin, showing a complex of interconnected sill intrusions extending more than $12 \mathrm{~km}(>7.5 \mathrm{mi})$ vertically and $20 \mathrm{~km}$ (12.4 mi) horizontally. Similarly, highly interconnected complexes of mafic intrusions are also observed in the FSB (Schofield et al., 2015) (Figure 2).

In the specific case of the intrusions penetrated by well 214/28-1, seismic reflection mapping shows that the overpressured intrusions form part of a larger, interconnected intrusive complex that can be traced toward the center of the basin, "rooting"

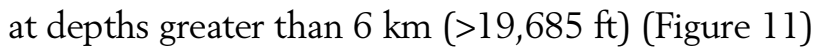
(Schofield et al., 2015; Mark et al., 2017). A continuous path can be traced from the $6.1-\mathrm{m}(20-\mathrm{ft})-$ thick overpressured intrusion penetrated by well $214 / 28-1$ at $4596 \mathrm{~m}$ BRT $(15,075 \mathrm{ft}$ BRT) via the interconnected intrusion to greater than $6 \mathrm{~km}$ $(>19,685 \mathrm{ft}$ ) in depth (Figure 11) on three-dimensional seismic data.

In well 219/28-2Z, the overpressured sill can be seen to be connected from approximately $3148 \mathrm{~m}$ BRT $(\sim 10,328 \mathrm{ft}$ BRT), where it was penetrated by the well to a "saucer-shaped" intrusion situated in the Lower Cretaceous at a depth of approximately
$4300 \mathrm{~m}$ BRT $(\sim 14,108 \mathrm{ft}$ BRT) (Figure 7). The saucer-shaped intrusion can be seen to be connected to a further inclined intrusion that extends down to a depth of approximately $7 \mathrm{~km}(\sim 22,965 \mathrm{ft})$ within the Lower Cretaceous (Figure 7).

Therefore, given the interconnected nature of intrusions, coupled with the evidence supporting the occurrence of open fracture systems within the intrusions, it seems plausible that intrusions may act as fractured conduits, hydraulically connecting separate pressure regimes within a basin. This would lead to apparent overpressure if intersected within the subsurface, although the overpressure is the result of pressure transmission from a deeper sequence.

A common concept used to explain the presence of overpressure within reservoir sand units is that of the centroid (Figure 12) (Traugott and Heppard, 1994; Swarbrick and Osborne, 1998), in which lateral pressure transfer occurs through a sand body that has become inclined (Swarbrick and Osborne, 1998). The centroid is the depth at which the pore pressure in the reservoir and bounding shale are in equilibrium, above the centroid, the pore pressure in the reservoir is higher than that of the bounding shale. Below the centroid, the reservoir pressure will be less than the surrounding shale (Traugott and Heppard, 1994). Tingay et al. (2007) adapted this concept to illustrate that overpressures could be transferred if an overpressured compartment comes into hydraulic communication with another lesspressured and isolated compartment, either by caprock fracturing or active faulting.

In the case of the abnormally pressured intrusions within wells 214/28-1 and 219/28-2Z, both suites of intrusions were penetrated by the wells situated near the intrusion tip (and therefore the shallowest depth of the entire intrusive complex), which can be seen to have climbed subvertically, crosscutting the stratigraphy over distances greater than $1 \mathrm{~km}(>\sim 3000 \mathrm{ft})$ vertically. Given the known overpressure that occurs within the shale-dominated Cretaceous succession of the FSB (Iliffe et al., 1999), it seems plausible that transference of pressure is occurring through the fractured intrusions, under a similar mechanism as proposed by Tingay et al. (2007). However, whereas the models of Tingay et al. (2007) and others are primarily concerned with generally subvertical to vertical transfer of overpressure, because of the highly interconnected 

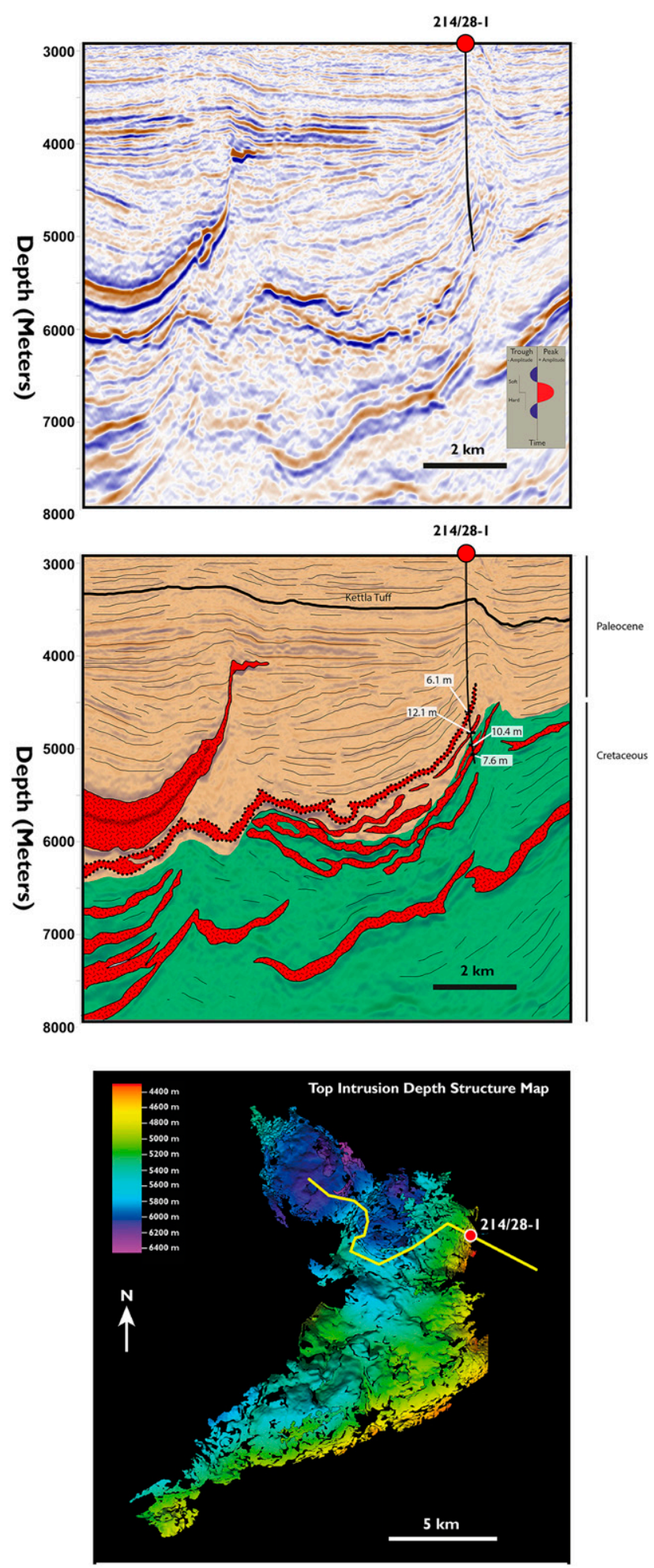

Figure 11. Seismic line through the 6.1-m (20-ft)-thick intrusion penetrated by well 214/28-1, highlighting the continuous path that can be traced vertically and horizontally through the intrusive body from the point of intersection at $4596 \mathrm{~m}$ below rotary table (BRT) $(15,078 \mathrm{ft}$ BRT) to a larger intrusive complex at depths greater than $6 \mathrm{~km}(>\sim 20,000 \mathrm{ft})$. and laterally extensive nature of the intrusive complexes, overpressures in the FSB could potentially be transferred laterally (and vertically) through a basin up to tens of kilometers away from the point of origin. Additionally, unlike the concept of the centroid, which relies on recent tilting of the sand body to produce differential pressures, in the case of intrusions, it is their crosscutting nature and tendency to intrude subvertically, which leads to pressure transfer and fluid drainage (Figure 12).

It is important to acknowledge that open fracture systems within intrusions are not universally prevalent within the FSB, and fractures can often be infilled by later fracture-filling cements (Rateau et al., 2013). Additionally, even if fractured, not all intrusions will carry overpressure. Out of the 29 wells that drilled intrusions within the FSB, only 2 of the wells, listed in this study, penetrated intrusions that had associated overpressure.

For an intrusion to become overpressured in the subsurface, it must satisfy several criteria. It must contain an open and extensive fracture network, be connected into a deeper pressure regime, and also be sealed by a suitable sealing lithology. If the intrusion intersects a permeable sand sequence, the overpressure will potentially bleed off into that sequence.

\section{Drilling Hazards: Are There Safety and Potential Environmental Issues with Petroleum and Scientific (for Example, International Ocean Drilling Program) Exploration in Volcanically Influenced Basins?}

Accurate prediction of subsurface fluid pressures is a critical element of all drilling, underpinning the design of safe wells (Board, 2012). Critically, pore pressure prediction underpins the well design. For example, the maximum pressure tolerance of a blowout preventer (BOP) and even the amount of barite and other chemicals kept on board a drilling rig to enable a rapid change in mud density are all reliant on predicting the likely pressure at a given depth. In mature basins, such as the North Sea, United Kingdom, or established areas of the Gulf of Mexico, where abundant primary well data exist, such prediction is generally well constrained, but in frontier areas, with sparse well control, pore pressure prediction can be highly challenging. 

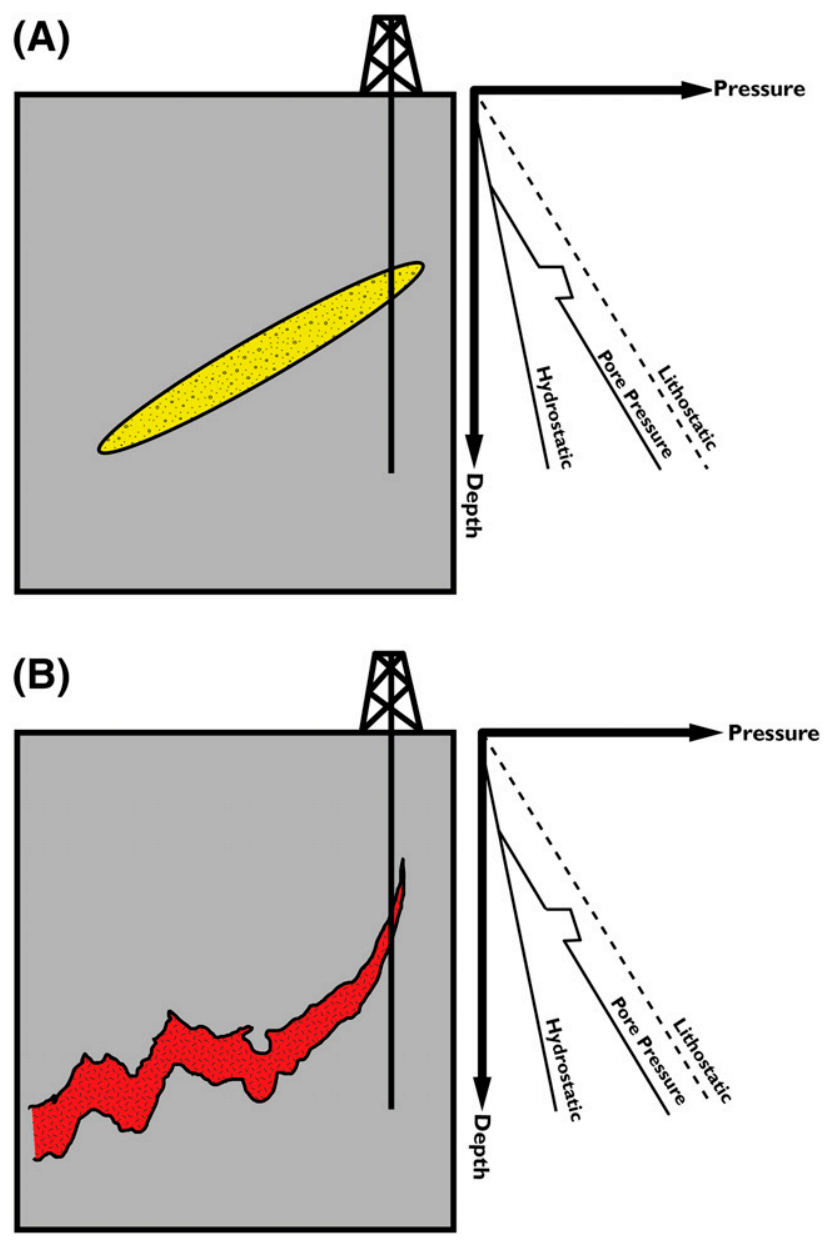

Figure 12. (A) Diagram showing concept of the centroid, which is commonly used to explain overpressure within sand bodies as a result of becoming inclined postdeposition (see Traugott and Heppard, 1994; Swarbrick and Osborne, 1998). (B) The modified concept of lateral drainage through a fractured intrusion. It is important to note that unlike the concept of the centroid, which relies on recent tilting of the sand body to produce differential pressures, in the case of intrusions, it is their crosscutting and tendency to intrude subvertically that lead to the pressure transfer and drainage, if connected at depth to more overpressured units.

Petroleum exploration wells are designed to be able to deal with (within a given tolerance) excess pore pressures. However, international ocean drilling program (IODP) riserless drilling is conducted with no BOP and primarily using seawater as the drilling fluid, meaning no primary (other than seawater) or secondary barrier exists to contain a potentially overpressured zone of fluids. The risk of encountering subsurface overpressure on IODP expedition drilling is usually minimized because zones of known potential overpressure (e.g., accretionary wedges; Westbrook and Smith, 1983) are avoided. Additionally, many expeditions target objectives within a few hundred meters of the seabed, which can be assumed to be in hydrostatic equilibrium from the seabed to the eventual termination point of the well. However, IODP drilling in basins effected by volcanism may be at risk from intersecting sheet intrusions connected to a deeper pressure regime, especially in deeper targets $(>1000 \mathrm{~m}$ [> 3000 ft] below sea floor), where the strength of host rock and sealing capacity may be sufficient to support overpressure connection via an interconnected intrusion to a deeper pressure compartment.

The maximum overpressure that can occur at a given depth is reliant on the sealing capacity of the host lithology in which an overpressured body is situated (Cartwright et al., 2007). The most effective lithologies at containing pressure are those with low permeabilities, including shales and mudstone, which sills are known to preferentially intrude (Schofield et al., 2012). The maximum overpressure that can be supported by a rock unit can be expressed in terms of the fracture gradient of the host rock (e.g., Figure 4), beyond which hydraulic fracturing and capillary leakage will occur and any overpressure can be assumed to dissipate. Following this scenario, a well being drilled in a geological sequence containing interconnected sill complexes may have only planned to drill to a depth of, for example, $4000 \mathrm{~m}$ BRT $(13,123 \mathrm{ft}$ BRT); however, if a fractured intrusion that is part of an interconnected complex plumbed into a deeper overpressure zone was penetrated, an overpressure magnitude up to the fracture gradient of the host rock could be encountered (Figure 13).

If during planning of the well, this scenario has not been identified, then the well design may not have the inbuilt tolerances to resist the abnormal pressures, leading to a worst-case scenario of a blowout, which brings a substantial risk to human life and the environment.

\section{Recommendation for Both Scientific (for Example, International Ocean Drilling Program) and Petroleum Drilling}

Sill intrusions have a fundamental underlying geological relationship, in terms of thickness, that directly impacts their ability to be imaged successfully using seismic reflection data. From studies of both 
well and field data, approximately $60 \%$ of intrusions fall less than $10 \mathrm{~m}(<35 \mathrm{ft})$ in thickness within sedimentary basins globally (Button and Cawthorn, 2015, Schofield et al., 2015; Mark et al., 2017; Eide et al., 2018; Svensen et al., 2014, 2016). This aspect on its own may not appear significant, but when it is considered in the context of the limitations of imaging of seismic reflection data, this can become an issue. Vertical seismic resolution in seismic surveys is typically in the range of tens of meters (Cartwright and Huuse, 2005), and at deep basin levels (e.g., 3-4 km [9842-13,123 ft]), vertical resolution can drop to a 40- to 80-m (131 - to 262-ft) range (Schofield et al., 2015). In the case of potential pressure transmission via intrusions, this is troublesome because it means that even if intrusions cannot be confidently interpreted from seismic reflection data in the vicinity of a well, they may still be present. This is illustrated in well 214/28-1, where the pressure kicks emanated from intrusions that were 6.1 and $7.6 \mathrm{~m}$ (20 and $25 \mathrm{ft}$ ) thick, respectively.

In areas containing pervasive subsurface intrusions, mitigating and predicting the risk of which intrusions may be fractured and overpressured is challenging. Detailed seismic mapping of intrusions may indicate deep connectivity, allowing some degree of mitigation during the well planning phase. During drilling activities, look-ahead resistivity tools (Constable et al., 2016) have the potential to alert drillers to the presence of subseismic intrusions before they are encountered; however, such tools are in a fledging stage of development (Constable et al., 2016). Additionally, there is a paucity of data on the look-ahead resistivity response of intrusions to permit assessment to whether an intrusion is either fractured, not fractured, or fractured and overpressured.

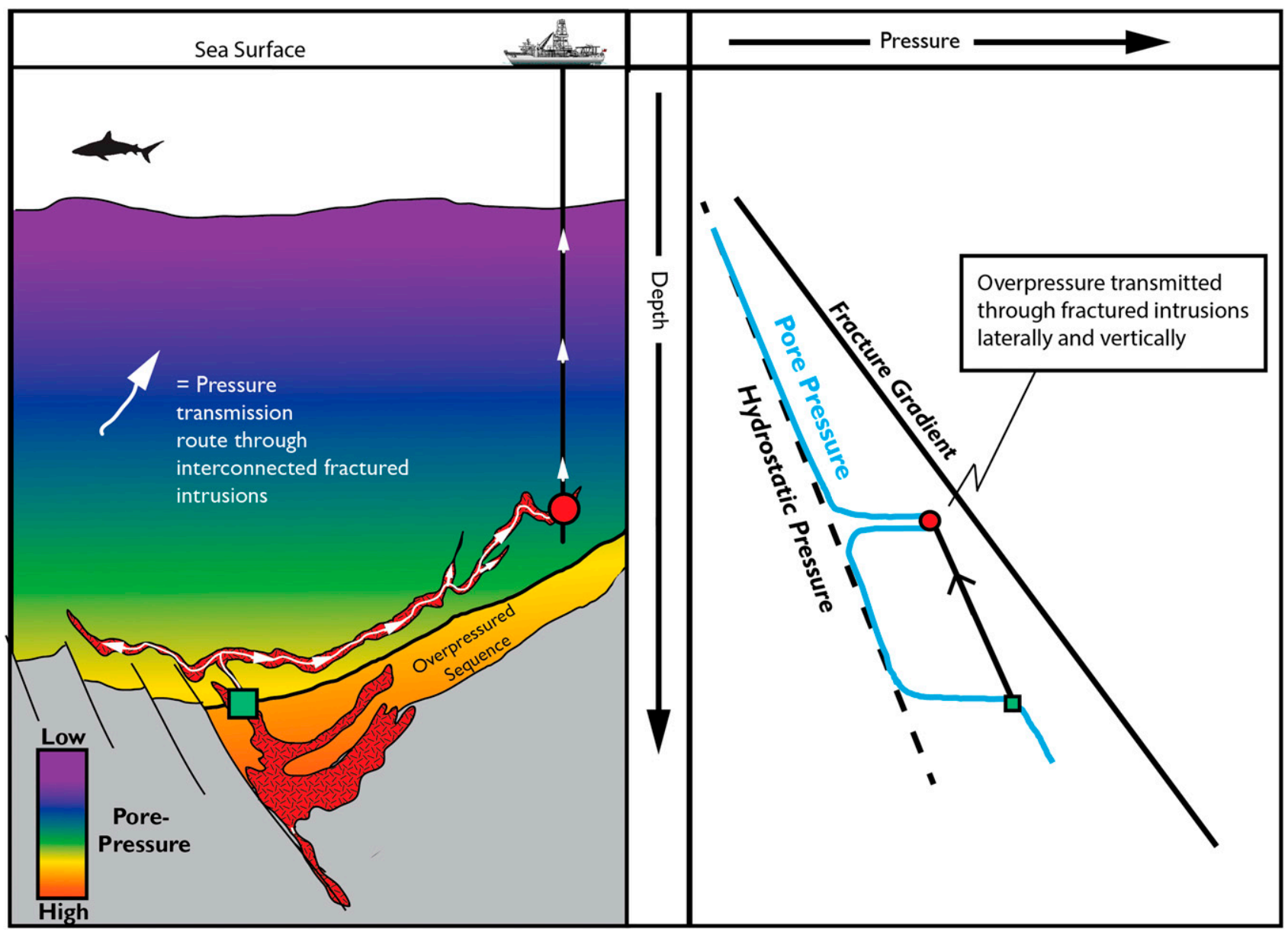

Figure 13. Conceptual diagram showing the principle of pressure transmission through a fractured igneous intrusive complex. Such a process can lead to overpressure being transferred laterally (and vertically) through a basin tens of kilometers away from its point of origin. 
In both scientific and commercial drilling operations in basins affected by intrusive volcanism, decisions should be underpinned by the recognition that the majority of intrusions will not be visible on seismic data and that intrusions in the region of a few meters are potentially capable of pressure transmission (Schofield et al., 2015; Mark et al., 2017).

\section{CONCLUSIONS}

We have detailed the occurrence of overpressure within intrusions of the FSB and propose a new pathway for overpressure transfer within sedimentary basins, namely the lateral and vertical transmission of pressure via vertically interconnected, fractured igneous intrusions. This mechanism is previously unrecognized and may represent a significant hazard to both scientific drilling (e.g., IODP) and drilling for oil and gas in the vicinity of interconnected transgressive igneous intrusive complexes in basins worldwide that contain substantial intrusive igneous complexes (e.g., northwest shelf of Australia, South Atlantic margin, Norwegian margin, Guaymas Basin).

\section{REFERENCES CITED}

Aarnes, I., H. Svensen, J. A. Connolly, and Y. Y. Podladchikov, 2010, How contact metamorphism can trigger global climate changes: Modelling gas generation around igneous sills in sedimentary basins: Geochimica et Cosmochimica Acta, v. 74, no. 24, p. 7179-7195, doi:10.1016 /j.gca.2010.09.011.

Baron, M., J. Parnell, D. Mark, A. Carr, M. Przyjalgowski, and M. Feely, 2008, Evolution of hydrocarbon migration style in a fractured reservoir deduced from fluid inclusion data, Clair field, west of Shetland, UK.: Marine and Petroleum Geology, v. 25, no. 2, p. 153-172, doi:10.1016 /j.marpetgeo.2007.05.010.

Bermúdez, A., and D. H. Delpino, 2008, Concentric and radial joint systems within basic sills and their associated porosity enhancement, Neuquén Basin, Argentina: Geological Society, London, Special Publications 2008, v. 302, p. 185-198, doi:10.1144/SP302.13.

Board, M., 2012, Macondo well deepwater horizon blowout: Lessons for improving offshore drilling safety: Washington, DC, National Academies Press, 196 p.

Booth, J., T. Swiecicki, and P. Wilcockson, 1993, The tectonostratigraphy of the Solan Basin, west of Shetland: Geological Society, London, Petroleum Geology Conference Series 1993, v. 4, p. 987-998, doi:10.1144/0040987
Bowers, G. L., 1995, Pore pressure estimation from velocity data: Accounting for overpressure mechanisms besides undercompaction: SPE Drilling \& Completion, v. 10, no. 2, p. 89-95, doi:10.2118/27488-PA.

Button, A., and R. G. Cawthorn, 2015, Distribution of mafic sills in the Transvaal Supergroup, northeastern South Africa.: Journal of the Geological Society, v. 172, no. 3, p. 357-367, doi:10.1144/jgs2014-101.

Cartwright, J., and M. Huuse, 2005, 3D seismic technology: The geological 'Hubble': Basin Research, v. 17, no. 1, p. 1-20, doi:10.1111/j.1365-2117.2005.00252.x.

Cartwright, J., M. Huuse, and A. Aplin, 2007, Seal bypass systems: AAPG Bulletin, v. 91, no. 8, p. 1141-1166, doi: 10.1306/04090705181.

Cartwright, J., and D. Møller Hansen, 2006, Magma transport through the crust via interconnected sill complexes: Geology, v. 34, no. 11, p. 929-932, doi:10.1130/G22758A.1.

Constable, M. V., F. Antonsen, S. O. Stalheim, P. A. Olsen, O. Z. Fjell, N. Dray, and S. Tan, 2016, Looking ahead of the bit while drilling: From vision to reality: Society of Petrophysicists and Well-Log Analysts 57th Annual Logging Symposium, Reykjavik, Iceland, June 25-29, 2016, 16 p.

Dodds, K., A. Fletcher, E. Bekele, A. Johnson, M. Hennig, W. Abriel, W. Higgs, and A. Strudley, 2001, An overpressure case history using a novel risk analysis process: APPEA Journal, v. 41, no. 1, p. 559-571, doi:10.1071/AJ00028.

Doré, A. G., E. R. Lundin, C. Fichler, and O. Olesen, 1997, Patterns of basement structure and reactivation along the NE Atlantic margin: Journal of the Geological Society, v. 154, no. 1, p. 85-92, doi:10.1144/gsjgs.154.1.0085.

Eide, C. H., N. Schofield, I. Lecomte, S. J. Buckley, and J. A. Howell, 2018, Seismic interpretation of sill complexes in sedimentary basins: Implications for the sub-sill imaging problem: Journal of the Geological Society, v. 175, no. 2, p. 193-209, doi:10.1144/jgs2017-096.

Ellis, D., D. W. Jolley, S. R. Passey, and B. R. Bell, 2009, Transfer zones: The application of new geological information from the Faroe Islands applied to the offshore exploration of intra basalt and sub-basalt strata, in T. Varming and H. Ziska, eds., Faroe Islands Exploration Conference: Proceedings of the 2nd Conference: Tórshavn, Faroe Islands, Annales Societatis Scientiarum Færoensis, p. 205-226.

Fan, C., Z. Wang, A. Wang, S. Fu, L. Wang, Y. Zhang, H. Kong, and X. Zhang, 2016, Identification and calculation of transfer overpressure in the northern Qaidam Basin, northwest China: AAPG Bulletin, v. 100, no. 1, p. 23-39, doi:10.1306/08031514030.

Gibb, F. G. F., and R. Kanaris-Sotiriou, 1988, The geochemistry and origin of the Faeroe-Shetland sill complex: Geological Society, London, Special Publications 1988, v. 39, p. 241-252, doi:10.1144/GSL.SP.1988.039.01.22.

Grace, R. D., 2017, Blowout and well control handbook: Houston, Texas, Gulf Professional Publishing, 472 p.

Grant, N., A. Bouma, and A. McIntyre, 1999, The Turonian play in the Faroe-Shetland basin, in A. J. Fleet and S. A. R. Boldy, eds., Petroleum geology of northwest Europe: Proceedings of the 5th Conference, London, October 26-29, 1997, p. 661-673. 
Grove, C., 2013, Submarine hydrothermal vent complexes in the Paleocene of the Faroe-Shetland Basin: Insights from three-dimensional seismic and petrographical data: Geology, v. 41, no. 1, p. 71-74, doi:10.1130/G33559.1.

Hardman, J., N, Schofield, D. Jolley, A. Hartley, S. Holford, and D. Watson, 2018a, Controls on the distribution of volcanism and intra-basaltic sediments in the CamboRosebank region, West of Shetland: Petroleum Geoscience, v. 25, no. 1, p. 71-89.

Hardman, J. P. A., N. Schofield, D. W. Jolley, S. P. Holford, A. J. Hartley, S. Morse, J. R. Underhill, D. A. Watson, and E. H. Zimmer, 2018b, Prolonged dynamic support from the Icelandic plume of the NE Atlantic margin: Journal of the Geological Society, v. 175, no. 3, p. 396-410, doi:10.1144/jgs2017-088.

Hitchen, K., and J. D. Ritchie, 1987, Geological review of the West Shetland area, in J. Brooks and K. W. Glennie, eds., Petroleum geology of north west Europe: London, Graham and Trotman, p.737-749.

Hoskin, E., S. O'Connor, S. Robertson, J. Streit, C. Ward, J. Lee, and D. Flett, 2015, Influence of faulting on reservoir overpressure distribution in the Northern Carnarvon Basin. APPEA Journal, v. 55, p. 35-48, doi: 10.1071/AJ14003

Iliffe, J. E., A. G. Robertson, G. H. F. Ward, C. Wynn, S. D. M. Pead, and N. Cameron, 1999, The importance of fluid pressures and migration to the hydrocarbon prospectivity of the Faroe-Shetland White Xone, in A. J. Fleet and S. A. R. Boldy, eds., Petroleum geology of northwest Europe: Proceedings of the 5th Conference, London, October 26-29, 1997, p. 601-611.

Lahann, R. W., D. McCarty, and J. Hsieh, 2001, Influence of clay diagenesis on shale velocities and fluid pressure: Offshore Technology Conference, Houston, Texas, April 30-May 3, 2001, OTC-13046-MS, 7 p.

Lamers, E., and S. M. M. Carmichael, 1999, The Paleocene deepwater sandstone play of West of Shetlands, in A. J. Fleet and S. A. R. Boldy, eds., Petroleum geology of northwest Europe: Proceedings of the 5th Conference, London, October 26-29, 1997, p. 645-659.

Luo, X., and G. Vasseur, 2016, Overpressure dissipation mechanisms in sedimentary sections consisting of alternating mud-sand layers: Marine and Petroleum Geoscience, v. 78, p. 883-894, doi:10.1016/j.marpetgeo 2016.04.001.

Mann, D. M., and A. S. Mackenzie, 1990, Prediction of pore fluid pressures in sedimentary basins: Marine and Petroleum Geology, v. 7, no. 1, p. 55-65, doi:10.1016 /0264-8172(90)90056-M.

Mark, N. J., N. Schofield, S. Pugliese, D. Watson, S. Holford, D. Muirhead, R. Brown, and D. Healy, 2017, Igneous intrusions in the Faroe Shetland basin and their implications for hydrocarbon exploration: New insights from well and seismic data: Marine and Petroleum Geology, v. 92, p. 733-753, doi:10.1016/J.MARPETGEO.2017 .12.005.

Moy, D. J., and J. Imber, 2009, A critical analysis of the structure and tectonic significance of rift-oblique lineaments ("transfer zones") in the Mesozoic-Cenozoic succession of the Faroe-Shetland Basin, NE Atlantic margin: Journal of the Geological Society, v. 166, no. 5, p. 831-844, doi:10.1144/0016-76492009-010.

Mudge, D. C., 2014, Regional controls on Lower Tertiary sandstone distribution in the North Sea and NE Atlantic margin basins, in T. McKie, P. T. S. Rose, A. J. Hartley, D. W. Jones, and T. L. Armstrong, eds., Tertiary deepmarine reservoirs of the North Sea region: Geological Society, London, Special Publications 2014, v. 403, p. 17-42.

Muirhead, D. K., S. A., Bowden, J. Parnell, and N. Schofield, 2017. Source rock maturation owing to igneous intrusion in rifted margin petroleum systems: Journal of the Geological Society, v. 174, no. 6, p. 979-987.

Neglia, S., 1979, Migration of fluids in sedimentary basins: AAPG Bulletin, v. 63, no. 4, p. 573-597.

Ogilvie, S., D. Barr, P. Roylance, and M. Dorling, 2015, Structural geology and well planning in the Clair field: Geological Society, London, Special Publications 2015, v. 421, p. 197-212, doi:10.1144/SP421.7.

Osborne, M. J., and R. E. Swarbrick, 1997, Mechanisms for generating overpressure in sedimentary basins: A reevaluation: AAPG Bulletin, v. 81, no. 6, p. 1023-1041.

Rateau, R., N. Schofield, and M. Smith, 2013, The potential role of igneous intrusions on hydrocarbon migration, West of Shetland: Petroleum Geoscience, v. 19, no. 3, p. 259-272, doi:10.1144/petgeo2012-035.

Ritchie, J. D., H. Johnson, M. F. Quinn, and R. W. Gatliff, 2008, The effects of Cenozoic compression within the Faroe-Shetland Basin and adjacent areas: Geological Society, London, Special Publications 2008, v. 306, p. 121-136, doi:10.1144/SP306.5.

Schofield, N., D. J. Brown, C. Magee, and C. T. Stevenson, 2012, Sill morphology and comparison of brittle and non-brittle emplacement mechanisms: Journal of the Geological Society, v. 169, no. 2, p. 127-141, doi: 10.1144/0016-76492011-078.

Schofield, N., S. Holford, J. Millet, D. Brown, D. Jolley, S. R. Passey, D. Muirhead et al., 2015, Regional magma plumbing and emplacement mechanisms of the FaroeShetland Sill Complex: Implications for magma transport and petroleum systems within sedimentary basins: Basin Research, v. 19, doi:10.1111/bre.12164.

Schofield, N., D. Jolley, S. Holford, S. Archer, D. Watson, A. Hartley, J. Howell, D. Muirhead, J. Underhill, and P. Green, 2017, Challenges of future exploration within the UK Rockall Basin: Geological Society, London, Petroleum Geology Conference Series 2017, v. 8, p. 211-229.

Scotchman, I., 2001, Petroleum geochemistry of the Lower and Middle Jurassic in Atlantic margin basins of Ireland and the UK, in P. M Shannon, P. D. W. Haughton, and D. V Corcoran, eds., The petroleum exploration of Ireland's offshore basins: Geological Society, London, Special Publications 2001, v. 188, p. 31-60, doi:10.1144 /GSL.SP.2001.188.01.03.

Scotchman, I. C., A. G. Doré, and A. M. Spencer, 2018, Petroleum systems and results of exploration on the Atlantic margins of the UK, Faroes \& Ireland: What have 
we learnt?: Geological Society, London, Petroleum Geology Conference Series 2018, v. 8, p. 187-197.

Senger, K., S. J. Buckley, L. Chevallier, A. Fagereng, O. Galland, T. H. Kurz, K. Ogata, S. Planke, and J. Tveranger, 2015, Fracturing of doleritic intrusions and associated contact zones: Implications for fluid flow in volcanic basins: Journal of African Earth Sciences, v. 102, p. 70-85, doi:10.1016/j.jafrearsci.2014.10.019.

Senger, K., S. Roy, A. Braathen, S. J. Buckley, K. Bælum, L. Gernigon, R. Mjelde, et al., 2013, Geometries of doleritic intrusions in central Spitsbergen, Svalbard: An integrated study of an onshore-offshore magmatic province with implications for $\mathrm{CO} 2$ sequestration.: Norwegian Journal of Geology, v. 93, p. 143-166.

Stoker, M. S., 2016, Cretaceous tectonostratigraphy of the Faroe-Shetland region: Scottish Journal of Geology, v. 52, no. 1, p. 19-41, doi:10.1144/sjg2016-004.

Stoker, M. S., S. P. Holford, R. R. Hillis, P. F. Green, and I. R. Duddy, 2010, Cenozoic post-rift sedimentation off northwest Britain: Recording the detritus of episodic uplift on a passive continental margin: Geology, v. 38, no. 7, p. 595-598, doi:10.1130/G30881.1.

Svensen, H. H., S. Polteau, G. Cawthorn, and S. Planke, 2014, Sub-volcanic intrusions in the Karoo basin, South Africa, in C. Breitkreuz and S. Rocchi, eds., Physical geology of shallow magmatic systems: Cham, Switzerland, Springer, p. 349-362, doi:10.1007/11157_2014_7.

Svensen, H. H., S. Polteau, G. Cawthorn, and S. Planke, 2016, Erratum to "Sub-volcanic Intrusions in the Karoo Basin, South Africa," in C. Breitkreuz and S. Rocchi, eds., Physical geology of shallow magmatic systems: Cham, Switzerland, Springer, p. E1, doi:10.1007/11157_2014_7.

Swarbrick, R. E. M. J. Osborne, 1998, Mechanisms that generate abnormal pressures; An overview, in B. E. Law, G. F. Ulmishck, and V. I. Slavin, eds., Abnormal pressures in hydrocarbon environments: AAPG Memoir 70, p. 13-34.

Swarbrick, R. E., M. J. Osborne, and G. S. Yardley, 2001, Comparison of overpressure magnitude resulting from the main generating mechanisms, in A. Huffman and G. Bowers, eds., Pressure Regimes in Sedimentary Basins and Their Prediction: AAPG Memoir 76, p. 1-12.

Tassone, D. R., S. P. Holford, M. S. Stoker, P. Greem, H. Johnson, J. R. Underhill, and R. R. Hillis, 2014, Constraining Cenozoic exhumation in the Faroe-Shetland region using sonic transit time data: Basin Research, v. 26 , no. 1, p. 38-72, doi:10.1111/bre.12052.
Tingate, P. R., A. Khaksar, P. van Ruth, D. N. Dewhurst, M. D. Raven, H. Young, R. R. Hillis, and K. Dodds, 2001, Geological controls on overpressure in the Northern Carnarvon Basin: APPEA Journal, v. 41, no. 1, p. 573-593, doi:10.1071/AJ00029.

Tingay, M., 2015, Initial pore pressures under the Lusi mud volcano, Indonesia: Interpretation, v. 3, p. 33-49.

Tingay, M. R., R. R. Hillis, R. E. Swarbrick, C. K. Morley, and A. R. Damit, 2007, "Vertically transferred" overpressures in Brunei: Evidence for a new mechanism for the formation of high-magnitude overpressure: Geology, v. 35, no. 11, p. 1023-1026, doi:10.1130/G23906A.1.

Tingay, M. R., C. K. Morley, A. Laird, O. Limpornpipat, K. Krisadasima, S. Pabchanda, and H. R. Macintyre, 2013, Evidence for overpressure generation by kerogento-gas maturation in the northern Malay Basin: AAPG Bulletin, v. 97, no. 4, p. 639-672, doi:10.1306/09041212032.

Traugott, M. O., and P. D. Heppard, 1994, Prediction of pore pressure before and after drilling-Taking the risk out of drilling overpressured prospects, Abnormal pressure in hydrocarbon environments: AAPG Hedberg Research Conference, Golden, Colorado, June 8-10, 1994, 12 p.

van Ruth, P., R. Hillis, R. Swarbrick, and P. Tingate, 2000, Mud weights, transient pressure tests and the distribution of overpressure in the North West Shelf, Australia: Petroleum Exploration Society Australia Journal, v. 28, p. 59-66.

van Ruth, P. J., R. R. Hillis, and R. E. Swarbrick, 2002, Detecting overpressure using porosity-based techniques in the Carnarvon Basin, Australia: APPEA Journal, v. 42, no. 1, p. 559-569, doi:10.1071/AJ01032.

Watson, D., N. Schofield, D. Jolley, S. Archer, A. J. Finlay, N. Mark, J. Hardman, and T. Watton, 2017, Stratigraphic overview of Palaeogene tuffs in the Faroe-Shetland Basin, NE Atlantic Margin: Journal of the Geological Society, v. 174, no. 4, p. 627-645, doi:10.1144/jgs2016-132.

Westbrook, G. K., and M. J. Smith, 1983, Long decollements and mud volcanoes: Evidence from the Barbados Ridge Complex for the role of high pore-fluid pressure in the development of an accretionary complex: Geology, v. 11, no. 5, p. 279-283, doi:10.1130/0091-7613(1983) $11<279$ :LDAMVE $>2.0 . C O ; 2$.

White, R., and D. McKenzie, 1989, Magmatism at rift zones: The generation of volcanic continental margins and flood basalts: Journal of Geophysical Research. Solid Earth, v. 94, no. B6, p. 7685-7729, doi:10.1029 /JB094iB06p07685. 